\title{
PERTUMBUHAN DAN PRODUKSI BAWANG MERAH (Allium ascalonicum L.) PADA PERLAKUAN PEMOTONGAN UMBI DAN BERBAGAI TAKARAN BOKASHI PUPUK KANDANG AYAM DI DESA WAEFUSI KECAMATAN NAMROLE KAB. BURU SELATAN
}

\author{
Iskandar Hamid \\ Dosen Fapertahut Uniqbu
}

\begin{abstract}
ABSTARK
Penelitian ini bertujuan untuk mengetahui pengaruh pemotongan umbi dan pemberian berbagai takaran bokashi pupuk kandang ayam terhadap pertumbuhan dan produksi bawang merah. Penelitian ini dilaksanakan berdasarkan rancangan acak kelompok dalam bentuk faktorial dua faktor dimana faktor pertama adalah pemotongan umbi bibit (p) yang terdiri dari tanpa pemotongan ujung umbi (p1) dan pemotongan ujung umbi ( $p 2$ ). Faktor kedua adalahperlakuan beberapa takaran bokashi pupuk kandang ayam (b) yang terdiri atas beberapa taraf yaitu $2 \mathrm{~kg}$ bokashi pupuk kandang ayam/petak (b1), $4 \mathrm{~kg}$ bokashi pupuk kandang ayam/petak (b2) dan $6 \mathrm{~kg}$ bokashi pupuk kandang ayam/petak (b3). Pemotongan umbi memberikan hasil terbaik pada tinggi tanaan pada umur 2 MST $(21,36 \mathrm{~cm}), 4$ MTS $(29,34 \mathrm{~cm}), 6$ MST $(34,14 \mathrm{~cm})$ dan 8 MST $(22,90 \mathrm{~cm})$. Jumlah daun umur 2 MST $(14,10$ helai), 4 MST (23,46 helai), 6 MST (27,51 helai), dan 8 MST (16, 57 helai); jumlah umbi (11,33); berat basah $(776,67 \mathrm{~g})$; berat kering umbi (443, $33 \mathrm{~g})$. Takaran bokashi pupuk kandang ayam $4 \mathrm{~kg}$ petak-1 menghasilkan rata-rata tertinggi pada tinggi tanaman $(31,84 \mathrm{~cm})$, jumlah daun $(26,53$ helai) jumlah umbi $(11,33)$, berat basah $(776,67)$ dan berat kering umbi $(443,33 \mathrm{~g})$. Terdapat interaksi yang berpengaruh nyata antara pemotongan umbi dan takaran bokashi pupuk kandang ayam $4 \mathrm{~kg}$ petak-1 yang berpengaruh terhadap pertumbuhan tanaman bawang merah.

Kata Kunci : Pertumbuhan, produksi.bawang merah
\end{abstract}

\section{PENDAHULUAN}

\subsection{Latar Belakang}

Indonesia terletak di daerah tropis yang memiliki dua musim yakni musim kemarau dan musim penghujan, sehinggga memungkinkan untuk mengembangkan beberapa jenis komoditas hortikultura. Indonesia yang memasuki era industri menyebabkan pemerintah menekankan pembangunan pertanian yang mengarah pada pola agribisnis dan agroindustri. Salah satu sub sektor pertanian yang dijalankan dengan sistem pertanian agribisnis adalah hortikultura. Bawang merah adalah salah satu komoditas hortikultura sayur-rempah yang telah lama dibudidayakan di Indonesia. Sayuran rempah ini banyak dibutuhkan terutama sebagai pelengkap bumbu masakan. Selain itu dapat juga digunakan sebagai obat tradisional yang banyak bermanfaat bagi kesehatan masyarakat karena mengandung senyawa alliin atau allisin.

Kebutuhan masyarakat akan bawang merah terus meningkat seiring dengan pertambahan jumlah penduduk dan peningkatan keragaman kebutuhan serta daya beli masyarakat yang semakin tinggi. Meningkatnya permintaan bawang merah tidak hanya dipasar dalam negeri tetapi juga diluar negeri sehingga membuka peluang ekspor. Tanaman bawang merah termasuk komoditas hortikultura multiguna yang ditinjau dari kandungan gizinya. Komposisi kimia bawang merah dalam tiap 100 gram yaitu 39,0 g protein; 0,3 g lemak; 0,2 g karbohidrat; 36,0 mg kalsium; $40,0 \mathrm{mg}$ fosfor; $0,8 \mathrm{mg}$ zat besi; $0,03 \mathrm{mg}$ vitamin B1; 2,0 vitamin C; dan 88,0 g air.

Komponen lain bawang merah adalah minyak atsiri dimana minyak atsiri inilah yang sebenarnya banyak dimanfaatkan untuk penyedap rasa makanan, bakterisida, fungisida dan berkhasiat obat-obatan (Rukmana 1994 ). Penurunan produktivitas bawang merah di Indonesia diakibatkan masih banyaknya petani yang kurang memperhatikan penerapan paket teknologi budidaya antara lain bibit yang tidak seragam dan klon yang tidak diketahui keunggulannya dengan daya tumbuh yang rendah, teknik pemotongan bibit yang salah, 
takaran pupuk rendah, pengendalian hama dan penyakit yang belum sempurna serta penanganan pasca panen yang belum optimal ( Mursiani, 2002 )

Petani di Indonesia menanam bawang merah dengan jalan memotong bagian ujung umbi bibit sepanjang kurang lebih sepertiga bagian umbi. Bibit yang digunakan berupa umbi yang telah mengalami penyimpanan untuk menghentikan masa dormansinya dimana masa dormansi umbi mempunyai korelasi dengan pertunasan, selain itu dengan pemotongan maka tanaman dapat tumbuh merata, dapat merangsang tumbuhnya tanaman tanaman, dapat merangsang tumbuhnya umbi samping, dapat mendorong tumbuhnya anakan dan daun sehingga banyak anakan yang banyak daunnya.

Usaha yang ditempuh untuk meningkatkan produksi bawang merah baik kualitas maupun kuantitasnya adalah dengan menggunakan pupuk. Pupuk merupakan bahan organik maupun anorganik yang diberikan ke dalam tanah dengan maksud mengganti kehilangan unsur hara. Kelebihan pupuk organik yakni mengandung unsur hara lengkap baik makro maupun mikro meskipun dalam jumlah yang sedikit. Selain itu pupuk organik lebih unggul dibanding pupuk anorganik dalam hal perbaikan struktur tanah, peningkatan daya serap tanah terhadap air, peningkatan kondisi kehidupan mikroorganisme dalam tanah, sumber nutrisi bagi tanaman dan ramah lingkungan.

Salah satu jenis pupuk organik yang sering digunakan adalah bokashi pupuk kandang ayam. Bokashi adalah salah satu permentasi bahan organik dengan inokulasi EM4 yang merupakan kultur campuran dari mikroorganisme yang menguntungkan bagi pertumbuhan tanaman seperti Laktobacillus sp, bakteri fotosintetik, actinomycetes dan ragi. Bokashi mempunyai banyak keunggulan antara lain kandungan unsur haranya sangat tinggi, kandungan mikroorganisme menguntungkan sangat tinggi, senyawa-senyawa organik yang dikandungnya cepat diserap oleh tanaman.

Pupuk kandang adalah pupuk yang berupa kotoran padat dan cair dari hewan ternak yang bercampur dengan sisa-sisa makanan maupun alas kandangnya.
Kandungan unsur hara dari pupuk kandang berbeda-beda karena masing-masing memiliki sifat khas. Keadaan keragaman ini disebabkan oleh faktor jenis hewan, umur, keadaan individu hewan, makanan, alas kandang, cara pengolahan dan penyimpanan pupuk kandang sebelum dipakai. Pupuk kandang ayam merupakan pupuk yang penguraiannya oleh mikroorganisme berlangsung cepat. Biasanya pupuk ini berada dalam bentuk padat dan cairnya mengandung unsur $N, P, K$, yang cukup tinggi dibanding pupuk kandang lainnya. Berdasarkan hal tersebut maka dilaksanakan penelitian ini untuk mengetahui pengaruh pemotongan umbi dan pemberian beberapa takaran bokashi pupuk kandang ayam terhadap pertumbuhan dan produksi bawang merah.

\subsection{Hipotesis}

1. Terdapat interaksi antara pemotongan umbi dengan perlakuan berbagai takaran bokashi pupuk kandang ayam yang memberikan hasil terbaik terhadap pertumbuhan dan produksi bawang merah.

2. Pemotongan umbi memberikan hasil terbaik terhadap pertumbuhan dan produksi bawang merah.

3. Terdapat salah satu perlakuan takaran bokashi pupuk kandang ayam yang memberikan hasil terbaik terhadap pertumbuhan dan produksi bawang merah.

\subsection{Tujuan dan Kegunaan}

Penelitian ini bertujuan untuk mengetahui pengaruh pemotongan umbi dan pemberian berbagai takaran bokashi pupuk kandang ayam terhadap pertumbuhan dan produksi bawang merah.

Kegunaannya adalah dapat menjadi petunjuk dan bahan pertimbangan dalam upaya pengembangan tanaman bawang merah yang baik dan sebagai bahan pembanding dalam penelitian selanjutnya.

\section{BAHAN DAN METODE}

\subsection{Tempat dan Waktu}

Penelitian ini dilaksanakan pada tahun 2016. Pelaksanaan penelitian ini di Desa Waefusi Kecamatan Namrole Kabupaten Buru Selatan 


\subsection{Bahan dan Alat}

Bahan-bahan yang digunakan adalah umbi bawang merah varietas Bima, pupuk bokashi kandang ayam, Urea, $\mathrm{KCl}$, TSP, Detain dan Furadan. Alat-alat yang digunakan adalah parang, patok, label, ember, mistar, dan alat tulis menulis.

\subsection{Metode Penelitian}

Penelitian ini dilaksanakan berdasarkan rancangan acak kelompok dalam bentuk faktorial dua faktor dimana faktor pertama adalah pemotongan umbi bibit $(p)$ yang terdiri dari tanpa pemotongan ujung umbi ( $\left.p_{1}\right)$ dan pemotongan ujung umbi $\left(p_{2}\right)$. Faktor kedua adalahperlakuan beberapa takaran bokashi pupuk kandang ayam (b) yang terdiri atas beberapa taraf yaitu $2 \mathrm{~kg}$ bokashi pupuk kandang ayam/petak (b 1$), 4 \mathrm{~kg}$ bokashi pupuk kandang ayam/petak (b $b_{2}$ dan $6 \mathrm{~kg}$ bokashi pupuk kandang ayam/petak $\left(b_{3}\right)$.

Setiap perlakuan dikombinasikan sehingga diperoleh 6 kombinasi perlakuan sebagai berikut :

$$
\begin{array}{ll}
\mathbf{p}_{1} \mathbf{b}_{1} & \mathbf{p}_{1} \mathbf{b}_{2} \\
\mathbf{p}_{2} \mathbf{b}_{1} & \mathbf{p}_{2} \mathbf{b}_{2}
\end{array}
$$

Setiap perlakuan diulang sebanyak $3 \mathrm{kali}$ sehingga terdapat 18 petak percobaan. Setiap petak terdiri dari 50 tanaman dengan demikian jumlah populasi seluruhnya adalah 900 tanaman. Tanaman contoh pada setiap petak dipilih secara acak sejumlah $\mathbf{1 0}$ tanaman.

\subsection{Pelaksanaan Penelitian}

\subsubsection{Pengolahan tanah}

Penyiapan lahan untuk pertanaman bawang merah yakni lahan yang akan digunakan terlebih dahulu dibersihkan dari gulma dan sisa-sisa tanaman. Pengolahan tanah dilakukan dengan mencangkul tanah sehingga tidak terjadi penggumpalan tanah. Penggemburan tanah, pembuatan bedengan dengan ukuran $2 \mathrm{~m} \times 1 \mathrm{~m}$, tinggi $20 \mathrm{~cm}$, lebar parit kira-kira $40 \mathrm{~cm}$ dengan kedalaman 40-50 cm.

\subsubsection{Pemupukan}

Pemupukan dilakukan dalam dua tahap yaitu sebelum penanaman sebagai pupuk dasar dan sesudah penanaman sebagai pupuk susulan. Pemberian pupuk urea dengan dosis sebanyak 150 kg/ha ( 30 g/petak ), TSP 125 kg/ha
(25 g/petak), KCl $326 \mathrm{~kg} / \mathrm{ha}(47,2 \mathrm{~g} /$ petak) dimana pupuk TSP dan $\mathrm{KCl}$ diberikan sekaligus pada saat tanam dengan cara dicampur rata dengan tanah. Pupuk Urea diberikan dua kali secara larikan masingmasing setengah dosis pupuk pada saat tanam dan sisanya oada umur empat minggu setelah tanam. Pemberian pupuk bokashi sebagai pupuk perlakuan yaitu pada saat penanaman sesuai takaran petakannya dengan cara disebar di atas permukaan tanah.

\subsubsection{Penanaman}

Bibit bawang merah yang digunakan adalah varietas Bima. Bibit bawang merah sebelum ditanam terlebih dahulu dipotong umbinya dengan jalan memotong $1 / 3$ bagian ujung umbi dengan menggunakan pisau tajam kemudian penanaman dilakukan dengan menanam bibit satu persatu sehingga 2/3 bagian siung masuk kedalam tanah dengan posisi siung tegak. Jarak tanam yang digunakan yakni ukuran $20 \mathrm{~cm}$ x $20 \mathrm{~cm}$.

\subsubsection{Pemeliharaan}

Pemeliharaan tanaman bawang merah melipputi 3 : pengairan, penyulaman, penyiangan dan prpenggemburan tanah, pemupukan, pemberantasan hama dan penyakit.

Penyiraman dilakukan 2 kali sehari pada pagi dan sore hari agar tanaman tidak kekeringan. Penyulaman dilakukan pada awal pertumbuhan hingga umur 7 hari setelah tanam dengan cara mengganti bibit yang mati atau busuk. Penyiangan dilakukan dengan mencabut gulma yang tumbuh disekitar tanaman serta pemberantasan hama dan penyakit dengan menggunakan pestisida seperti detain dan furadan.

\subsubsection{Panen}

Tanaman dapat dipanen pada umur 70 hari setelah tanam dengan kriteria panen antara lain tanaman telah cukup tua, hamper 60-90\% leher batang lemas dan daun-daunnya menguning, umbi lapis sudah kelihatan penuh (padat) berisi dan muncul sebagian diatas permukaan tanah dan warna umbinya merah mengkilap.

Pemaneman sebaiknya dilakukan pada saat cuaca cerah, tidak ada hujan dan pada pagi hari dengan cara mencabut tanaman secara hatihati agar batangnya tidak putus dan umbinya tidak tinggal dalam tanah. Setelah dicabut 
kemudian umbi dikumpulkan dan dibersihkan dari tanah yang melekat. Selanjutnya umbi diikat pada bagian batangnya lalu diangkut pada tempat penyimpanan sementara.

\subsection{Komponen Pengamatan}

1. Tinggi tanaman per rumpun $(\mathrm{cm})$, diukur dari pangkal tanaman sampai ujung daun, pada umur 30 hari setelah tanam.

2. Jumlah daun per rumpun, dihitung pada umur 30 hari setelah tanam.

3. Jumlah umbi per rumpun, diamati setelah panen dengan menghitung jumlah tiap umbi yang dihasilkan dalam satu rumpun.

4. Umur panen ( hari ) dihitung sejak hari penanaman sampai saat tanaman akan dipanen.
5. Bobot umbi basah per rumpun (g), ditimbang saat umbi sudah dibersihkan dari akar dan daunnya.

6. Bobot umbi kering per rumpun (g), ditimbang setelah dikering anginkan selama 3 hari.

\section{HASIL DAN PEMBAHASAN}

\subsection{Hasil}

\subsubsection{Tinggi Tanaman}

Tinggi tanaman bawang merah umur 2, 4, 6 dan 8 MST serta sidik ragamnya disajikan pada Tabel Lampiran 1a, 1b, 2a, 2b, 3a, 3b, 4a dan 4 b. Sidik ragam menunjukkan bahwa pemotongan ujung umbi dan berbagai dosis bokashi pupuk kandang ayam sangat berpengaruh nyata, sedangkan interaksi keduanya tidak berpengaruh nyata terhadap tinggi tanaman pada umur 2, 4, 6 dan 8 MST.

Tabel 1. Rata-rata tinggi tanaman $(\mathrm{cm})$ bawang merah

\begin{tabular}{|c|c|c|c|c|c|c|}
\hline \multirow{3}{*}{ ur } & \multirow{3}{*}{$\begin{array}{l}\text { Pemotongan Ujung } \\
\text { Umbi (P) }\end{array}$} & \multicolumn{3}{|c|}{$\begin{array}{c}\text { Bokashi Pupuk Kandang } \\
\left.\text { Ayam (kg petak }{ }^{-1}\right) \\
\end{array}$} & \multirow{3}{*}{$\begin{array}{l}\text { Rat } \\
\text { a-rata }\end{array}$} & \multirow{3}{*}{$\begin{array}{r}\mathrm{NP} \\
\mathrm{BNT}_{0,01}\end{array}$} \\
\hline & & 2 & 4 & 6 & & \\
\hline & & $\left(b_{1}\right)$ & $\left(\mathbf{b}_{2}\right)$ & $\left(b_{3}\right)$ & & \\
\hline \multirow{3}{*}{$\mathrm{MST}^{2\left(\mathrm{p}_{1}\right)}$} & Tanpa Pemotongan & 7,66 & $8^{12,5}$ & 9,49 & b 9,91 & 1,4524 \\
\hline & \multirow{2}{*}{ Pemotongan ( $\left.\mathrm{p}_{2}\right)$} & 20,2 & 24,1 & 19,6 & 21,3 & \\
\hline & & 4 & 8 & 7 & $6^{\mathrm{a}}$ & \\
\hline & \multirow{2}{*}{ Rata-rata } & 13,9 & 18,3 & 14,5 & & \\
\hline & & $5^{b}$ & $8^{a}$ & $8^{\mathrm{b}}$ & & \\
\hline & \multirow{2}{*}{$\mathrm{NP}_{\mathrm{BNT}} \mathrm{BN}_{0,01}$} & 1,77 & & & & \\
\hline & & 88 & & & & \\
\hline \multirow{8}{*}{$\operatorname{MST}^{4 \quad\left(\mathrm{p}_{1}\right)}$} & Tanpa Pemotongan & 12,8 & 21,4 & 17,5 & 17,2 & \multirow{4}{*}{2,9768} \\
\hline & & 4 & 0 & 4 & $6^{\mathrm{b}}$ & \\
\hline & \multirow{2}{*}{ Pemotongan $\left(\mathrm{p}_{2}\right)$} & 25,5 & 32,6 & 29,7 & 29,3 & \\
\hline & & 8 & 4 & 9 & $4^{a}$ & \\
\hline & \multirow{2}{*}{ Rata-rata } & 19,2 & 27,0 & 23,6 & & \\
\hline & & $1^{b}$ & $2^{a}$ & $7^{a}$ & & \\
\hline & \multirow{2}{*}{ NP BNT 0,01} & 3,64 & & & & \\
\hline & & 59 & & & & \\
\hline & Tanpa $\quad$ Pemotongan & 17,5 & 25,7 & 21,2 & 21,5 & \multirow{4}{*}{1,6541} \\
\hline $6\left(p_{1}\right)$ & & 0 & 7 & 6 & $1^{b}$ & \\
\hline MST & \multirow{2}{*}{ Pemotongan $\left(\mathrm{p}_{2}\right)$} & 30,6 & 37,9 & 33,8 & 34,1 & \\
\hline & & 7 & 0 & 6 & $4^{a}$ & \\
\hline & \multirow{2}{*}{ Rata-rata } & 24,0 & 31,8 & 27,5 & & \\
\hline & & $9^{c}$ & $4^{a}$ & $6^{\mathrm{b}}$ & & \\
\hline & \multirow{2}{*}{ NP BNT 0,01} & 2,02 & & & & \\
\hline & & 58 & & & & \\
\hline 8 & Tanpa Pemotongan & 890 & 18,0 & 13,5 & 13,5 & \multirow{2}{*}{3,5495} \\
\hline $\operatorname{MST} \quad\left(p_{1}\right)$ & & 0,90 & 5 & 4 & $0^{\mathrm{b}}$ & \\
\hline
\end{tabular}




\begin{tabular}{ccccc} 
Pemotongan $\left(\mathrm{p}_{2}\right)$ & $1^{17,1}$ & $6^{28,4}$ & $4^{23,1}$ & $0^{\mathrm{a}}$ \\
\hline Rata-rata & $1^{\mathrm{13}, 0}$ & $6^{23,2}$ & $6^{\mathrm{a}}$ & $4^{\mathrm{b}}$ \\
\hline NP BNT $_{0,01}$ & $7^{4,34}$ & & \\
\hline
\end{tabular}

Keterangan : Angka-angka yang diikuti oleh huruf yang berbeda berarti berbeda nyata pada taraf uji $\mathrm{BNT}_{\alpha}=0,01$

Tabel 1 menunjukkan bahwa pemotongan ujung umbi $\left(\mathrm{p}_{2}\right)$ menghasilkan tanaman tertinggi pada umur 2 MST $(21,36 \mathrm{~cm})$, 4 MST $(29,34 \mathrm{~cm}), 6$ MST $(34,14 \mathrm{~cm})$ dan 8 MST $(22,90 \mathrm{~cm})$ dan sangat berbeda nyata dengan tanpa pemotongan ujung umbi.

Dosis bokashi pupuk kandang ayam $4 \mathrm{~kg}$ petak $^{-1}\left(b_{2}\right)$ menghasilkan tanaman tertinggi pada umur 2 MST $(18,38 \mathrm{~cm}), 4$ MST $(27,02 \mathrm{~cm})$, 6 MST $(31,84 \mathrm{~cm})$ dan 8 MST $(23,36 \mathrm{~cm})$ dan sangat berbeda nyata dengan dosis $2\left(b_{1}\right)$ dan 6 $\mathrm{kg}$ petak $^{-1}\left(\mathrm{~b}_{3}\right)$ pada umur 2, 6 dan $8 \mathrm{MST}$, tetapi tidak berbeda nyata dengan dosis $6 \mathrm{~kg}^{\text {petak }}{ }^{-1}$ pada umur 4 MST.

3.1.2. Jumlah Daun

Jumlah daun tanaman bawang merah umur 2, 4, 6 dan 8 MST serta sidik ragamnya disajikan pada Tabel Lampiran 5a, 5b, 6a, 6b, $7 a, 7 b, 8 a$ dan $8 b$. Sidik ragam menunjukkan bahwa pemotongan ujung umbi berpengaruh sangat nyata pada umur 2, 4, 6 dan 8 MST, berbagai dosis bokashi pupuk kandang ayam sangat berpengaruh nyata pada umur 4, 6 dan 8 MST serta nyata pada umur 2 MST, sedangkan interaksi keduanya tidak berpengaruh nyata terhadap jumlah daun pada umur 2, 4, 6 dan 8 MST.

Tabel 2 menunjukkan bahwa pemotongan ujung umbi $\left(\mathrm{p}_{2}\right)$ menghasilkan jumlah daun terbanyak pada umur 2 MST (14,10 helai), 4 MST (23,46 helai), 6 MST (27,51 helai) dan 8 MST (16,57 helai) dan sangat berbeda nyata dengan tanpa pemotongan ujung umbi.

Tabel 2. Rata-rata jumlah daun (helai) tanaman bawang merah

\begin{tabular}{|c|c|c|c|c|c|c|}
\hline \multirow{3}{*}{ ur } & \multirow{3}{*}{$\begin{array}{l}\text { Pemotongan Ujung } \\
\text { Umbi (P) }\end{array}$} & \multicolumn{3}{|c|}{$\begin{array}{c}\text { Bokashi Pupuk Kandang } \\
\left.\text { Ayam (kg petak }{ }^{-1}\right)\end{array}$} & \multirow{3}{*}{$\begin{array}{l}\text { Rat } \\
\text { a-rata }\end{array}$} & \multirow{3}{*}{$\begin{array}{r}\mathrm{NP} \\
\mathrm{BNT}_{0,01}\end{array}$} \\
\hline & & 2 & 4 & 6 & & \\
\hline & & $\left(b_{1}\right)$ & $\left(b_{2}\right)$ & $\left(b_{3}\right)$ & & \\
\hline \multirow{3}{*}{$\operatorname{MST}^{2\left(\mathrm{p}_{1}\right)}$} & Tanpa Pemotongan & 5,10 & 8,87 & 5,90 & b 6,62 & 2,8930 \\
\hline & \multirow{2}{*}{ Pemotongan $\left(\mathrm{p}_{2}\right)$} & 13,8 & 16,5 & 11,9 & 14,1 & \\
\hline & & 0 & 3 & 7 & $0^{\mathrm{a}}$ & \\
\hline & \multirow{2}{*}{ Rata-rata } & 9,45 & 12,7 & 8,93 & & \\
\hline & & b & $0^{\mathrm{a}}$ & $\mathbf{b}$ & & \\
\hline & \multirow{2}{*}{ NP BNT 0,01} & 2,49 & & & & \\
\hline & & 10 & & & & \\
\hline \multirow{8}{*}{ MST $^{4}$} & Tanpa Pemotongan & 11,7 & 18,3 & 14,7 & 14,9 & \multirow{4}{*}{2,1948} \\
\hline & & 7 & 7 & 3 & $6^{\mathrm{b}}$ & \\
\hline & \multirow{2}{*}{ Pemotongan $\left(\mathrm{p}_{2}\right)$} & 19,9 & 27,8 & 22,5 & 23,4 & \\
\hline & & 7 & 7 & 3 & $6^{a}$ & \\
\hline & \multirow{2}{*}{ Rata-rata } & 15,8 & 23,1 & 18,6 & & \\
\hline & & $7^{c}$ & $2^{a}$ & $3^{b}$ & & \\
\hline & \multirow{2}{*}{ NP BNT 0,01} & 2,68 & & & & \\
\hline & & 81 & & & & \\
\hline \multirow{5}{*}{$\mathrm{MST}^{6\left(\mathrm{p}_{1}\right)}$} & Tanpa $\quad$ Pemotongan & 15,5 & 21,0 & 17,0 & 17,8 & \multirow{4}{*}{3,6243} \\
\hline & & 7 & 0 & 3 & $7^{\mathrm{b}}$ & \\
\hline & \multirow{2}{*}{ Pemotongan $\left(\mathrm{p}_{2}\right)$} & 22,6 & 32,0 & 27,8 & 27,5 & \\
\hline & & 3 & 7 & 3 & $\mathbf{1}^{\mathrm{a}}$ & \\
\hline & Rata-rata & 19,1 & 26,5 & 22,4 & & \\
\hline
\end{tabular}




\begin{tabular}{|c|c|c|c|c|c|c|}
\hline & & $0^{\mathrm{b}}$ & $3^{a}$ & $3^{\mathrm{ab}}$ & & \\
\hline & NP BNT 0,01 & $88^{4,43}$ & & & & \\
\hline \multirow{6}{*}{$\operatorname{MST}^{8 \quad\left(p_{1}\right)}$} & Tanpa Pemotongan & 5,63 & 9,70 & 7,87 & b & 3,4740 \\
\hline & \multirow{2}{*}{ Pemotongan $\left(\mathrm{p}_{2}\right)$} & 11,2 & 21,9 & 16,4 & 16,5 & \\
\hline & & 7 & 7 & 7 & $7^{a}$ & \\
\hline & \multirow{2}{*}{ Rata-rata } & 8,45 & 15,8 & 12,1 & & \\
\hline & & $\mathbf{b}$ & $3^{\mathrm{a}}$ & $7^{\mathrm{ab}}$ & & \\
\hline & NP $B_{N T} T_{0,01}$ & $4^{4,25}$ & & & & \\
\hline
\end{tabular}

Keterangan : Angka-angka yang diikuti oleh huruf yang berbeda berarti berbeda nyata pada taraf uji $\mathrm{BNT}_{\alpha}=0,01$

Dosis bokashi pupuk kandang ayam $4 \mathrm{~kg}$ petak $^{-1} \quad\left(b_{2}\right)$ menghasilkan jumlah daun terbanyak pada umur 2 MST (12,70 helai), 4 MST (23,12 helai), 6 MST (26,53 helai) dan 8 MST (15,83 helai) dan sangat berbeda nyata dengan dosis $2\left(b_{1}\right)$ dan $6 \mathrm{~kg}$ petak $^{-1}\left(b_{3}\right)$ pada umur 2 dan 4 MST, tetapi tidak berbeda nyata dengan dosis $6 \mathrm{~kg}^{\text {petak }}{ }^{-1}$ pada umur 6 dan 8 MST.

\subsubsection{Jumlah Umbi}

Jumlah umbi tanaman bawang merah dan sidik ragamnya disajikan pada Tabel Lampiran 9a dan 9b. Sidik ragam menunjukkan bahwa pemotongan ujung umbi, berbagai dosis bokashi pupuk kandang ayam dan interaksi keduanya sangat berpengaruh nyata terhadap jumlah umbi.

Tabel 3. Rata-rata jumlah umbi tanaman bawang merah

\begin{tabular}{|c|c|c|c|c|}
\hline \multirow{2}{*}{$\begin{array}{c}\text { Pemotongan Ujung } \\
\text { Umbi (P) }\end{array}$} & \multicolumn{3}{|c|}{$\begin{array}{c}\text { Bokashi Pupuk Kandang Ayam } \\
\left.\text { (kg petak }{ }^{-1}\right)\end{array}$} & \multirow{2}{*}{$\begin{array}{r}\mathrm{NP} \\
\mathrm{BNT}_{0,01}\end{array}$} \\
\hline & $2\left(b_{1}\right)$ & $4\left(b_{2}\right)$ & $6\left(b_{3}\right)$ & \\
\hline Tanpa Pemotongan ( $\left.\mathrm{p}_{1}\right)$ & $6,23^{c}$ & $7,77^{\mathrm{b}}$ & $7,07^{b c}$ & 1,3948 \\
\hline Pemotongan $\left(\mathrm{p}_{2}\right)$ & $7,67^{\mathrm{b}}$ & $11,33^{\mathrm{a}}$ & $7,90^{\mathrm{b}}$ & \\
\hline
\end{tabular}

Keterangan : Angka-angka yang diikuti oleh huruf yang berbeda berarti berbeda nyata pada taraf uji $\mathrm{BNT}_{\alpha}=0,01$

Tabel 3 menunjukkan bahwa pemotongan ujung umbi yang diberikan bokashi pupuk kandang ayam dengan dosis 4 $\mathrm{kg}$ petak $^{-1}\left(\mathrm{p}_{2} \mathrm{~b}_{2}\right)$ menghasilkan jumlah umbi terbanyak $(11,33)$ dan sangat berbeda nyata dengan perlakuan lainnya.

\subsubsection{Berat Basah Umbi}

Berat basah umbi tanaman bawang merah dan sidik ragamnya disajikan pada
Tabel Lampiran 10a dan 10b. Sidik ragam menunjukkan bahwa pemotongan ujung umbi dan berbagai dosis bokashi pupuk kandang ayam sangat berpengaruh nyata, sedangkan interaksi keduanya berpengaruh nyata terhadap berat basah umbi.

Tabel 4. Rata-rata berat basah umbi (g) tanaman bawang merah

\begin{tabular}{|c|c|c|c|c|}
\hline \multirow{2}{*}{$\begin{array}{c}\text { Pemotongan Ujung } \\
\text { Umbi (P) }\end{array}$} & \multicolumn{3}{|c|}{$\begin{array}{c}\text { Bokashi Pupuk Kandang Ayam } \\
\left(\text { kg petak }^{-1}\right)\end{array}$} & \multirow{2}{*}{$\begin{array}{r}\text { NP } \\
\text { BNT }_{0,05}\end{array}$} \\
\hline & $2\left(b_{1}\right)$ & $4\left(b_{2}\right)$ & $6\left(b_{3}\right)$ & \\
\hline Tanpa Pemotongan ( $\left.\mathrm{p}_{1}\right)$ & $473,33^{\mathrm{b}}$ & $516,67^{\mathrm{b}}$ & $483,33^{b}$ & 101,8898 \\
\hline Pemotongan $\left(\mathrm{p}_{2}\right)$ & $533,33^{\mathrm{b}}$ & $776,67^{\mathrm{a}}$ & $556,67^{\mathrm{b}}$ & \\
\hline
\end{tabular}


Tabel 4 menunjukkan bahwa pemotongan ujung umbi yang diberikan bokashi pupuk kandang ayam dengan dosis 4 kg petak $^{-1}\left(\mathrm{p}_{2} \mathrm{~b}_{2}\right)$ menghasilkan umbi basah terberat $(776,67 \mathrm{~g})$ dan sangat berbeda nyata dengan perlakuan lainnya.

\subsubsection{Berat Kering Umbi}

Berat kering umbi tanaman bawang merah dan sidik ragamnya disajikan pada Tabel Lampiran 11a dan 11b. Sidik ragam menunjukkan bahwa pemotongan ujung umbi, berbagai dosis bokashi pupuk kandang ayam dan interaksi keduanya sangat berpengaruh nyata terhadap berat kering umbi.

Tabel 5. Rata-rata berat kering umbi (g) tanaman bawang merah

\begin{tabular}{ccccc}
\hline \multirow{2}{*}{$\begin{array}{c}\text { Pemotongan Ujung } \\
\text { Umbi (P) }\end{array}$} & \multicolumn{3}{c}{$\begin{array}{c}\text { Bokashi Pupuk Kandang Ayam } \\
\left(\text { kg petak }^{-1}\right)\end{array}$} & $\begin{array}{c}\text { NP } \\
\text { BNT }_{0,01}\end{array}$ \\
\cline { 2 - 4 } & $2\left(\mathrm{~b}_{1}\right)$ & $4\left(\mathrm{~b}_{2}\right)$ & $6\left(\mathrm{~b}_{3}\right)$ & \\
\hline Tanpa Pemotongan $\left(\mathrm{p}_{1}\right)$ & $150,00^{\mathrm{c}}$ & $183,33^{\mathrm{bc}}$ & $160,00^{\mathrm{c}}$ & $\mathbf{9 7 , 2 4 4 3}$ \\
Pemotongan (p $\left.\mathrm{p}_{2}\right)$ & $193,33^{\mathrm{bc}}$ & $443,33^{\mathrm{a}}$ & $276,67^{\mathrm{b}}$ & \\
\hline
\end{tabular}

Keterangan : Angka-angka yang diikuti oleh huruf yang berbeda berarti berbeda nyata pada taraf uji BNT $_{\alpha}=0,01$

Tabel 5 menunjukkan bahwa pemotongan ujung umbi yang diberikan bokashi pupuk kandang ayam dengan dosis 4 kg petak $^{-1}\left(\mathrm{p}_{2} \mathrm{~b}_{2}\right)$ menghasilkan umbi kering terberat $(443,33 \mathrm{~g})$ dan sangat berbeda nyata dengan perlakuan lainnya.

3.1.6. Umur Panen

Umur panen umbi tanaman bawang merah dan sidik ragamnya disajikan pada
Tabel Lampiran 12a dan 12b. Sidik ragam menunjukkan bahwa pemotongan ujung umbi sangat berpengaruh nyata, berbagai dosis bokashi pupuk kandang ayam dan interaksi keduanya tidak berpengaruh nyata terhadap umur panen umbi.

Tabel 6. Rata-rata umur panen (hari) tanaman bawang merah

\begin{tabular}{|c|c|c|c|c|c|}
\hline \multirow[t]{2}{*}{$\begin{array}{c}\text { Pemotongan Ujung } \\
\text { Umbi (P) }\end{array}$} & \multicolumn{3}{|c|}{$\begin{array}{l}\text { Bokashi Pupuk Kandang Ayam } \\
\left(\text { kg petak }^{-1}\right)\end{array}$} & \multirow{2}{*}{$\begin{array}{l}\text { Rata } \\
\text {-rata }\end{array}$} & \multirow{2}{*}{$\begin{array}{r}\mathrm{NP} \\
\mathrm{BNT}_{0,01}\end{array}$} \\
\hline & $2\left(b_{1}\right)$ & $4\left(b_{2}\right)$ & $6\left(b_{3}\right)$ & & \\
\hline \multirow[b]{2}{*}{ Tanpa Pemotongan $\left(\mathrm{p}_{1}\right)$} & & & & 70,0 & 4,243 \\
\hline & 71,00 & 70,67 & 68,33 & $\begin{array}{l}0^{\mathrm{b}} \\
60,2\end{array}$ & 3 \\
\hline Pemotongan $\left(\mathrm{p}_{2}\right)$ & 60,67 & 60,33 & 59,67 & $2^{\mathrm{a}}$ & \\
\hline
\end{tabular}

Keterangan : Angka-angka yang diikuti oleh huruf yang berbeda berarti berbeda nyata pada taraf uji $\mathrm{BNT}_{\alpha}=0,01$

Tabel 6 menunjukkan bahwa pemotongan ujung umbi $\left(\mathrm{p}_{2}\right)$ menghasilkan um,ur panen tercepat $(60,22$ hari) dan sangat berbeda nyata dengan tanpa pemotongan ujung umbi.

\subsection{Pembahasan}

\subsubsection{Pemotongan Umbi}

Hasil analisis statistik menunjukkan bahwa perlakuan pemotongan umbi memberikan hasil terbaik pada tinggi tanaman umur 2, 4, 6 dan 8 MST, jumlah daun; jumlah umbi; berat basah; berat kering dan umur panen. Hal ini disebabkan pemotongan umbi merupakan suatu perlakuan untuk mempengaruhi fase vegetatif dan fase reproduktif tanaman. Dengan pemotongan umbi berarti memacu pertumbuhan tunas sehinggga tanaman dapat tumbuh dengan merata. Hal ini sesuai dengan pendapat Wibowo ( 2005 ) bahwa dengan memotong umbi berarti memacu fase vegetatif dimana pemotongan umbi bertujuan menumbuhkan tunas umbi yang ditanam dengan cepat.

Pemotongan umbi merupakan cara yang banyak dilakukan sebelum penanaman pada 
tanaman bawang merah, hal ini dilakukan untuk mempermudah dan mempercepat pertumbuhan tanaman. Setelah umbi mengakhiri masa dormansi maka tunas mulai tumbuh yang diawali dengan munculnya tunas apikal diujung umbi. Pertumbuhan tunas tersebut menggunakan energi yang berasal dari umbi bibit atau umbi induk dengan cara merombak pati serta protein oleh senyawa yang dihasilkan mata tunas. Hal ini sesuai dengan pendapat Sugiharto ( 1992 ) bahwa sebelum umbi ditanam pada tanaman bawang merah pada umumnya dilakukan pemotongan ujung umbi terlebih dahulu dengan tujuan menghilangkan dormansi apikal agar nantinya memacu pertumbuhan tunas dan membentuk pertumbuhan tanaman yang lebih seragam.

Pembuangan ujung umbi pada tanaman bawang merah akan mempengaruhi saat munculnya tanaman diatas permukaan tanah, saat munculnya tanaman tersebut mempunyai hubungan yang erat dengan pola pertumbuhan tanaman. Apabila umbi yang ditanam sudah membentuk tunas baru maka tanaman akan lebih cepat tumbuh. Adanya nisbah daun dan akar yang tinggi akan mempercepat pertumbuhan tanaman dan pembentukan umbi baru sebaliknya apabila nisbah tersebut rendah akan menghambat saat inisiasi umbi selanjutnya. Hal ini sesuai dengan pendapat Rahayu dan Berlian ( 1999 ) bahwa bawang merah dapat diperbanyak dengan menggunakan umbi, pemotongan umbi akan mempengaruhi saat munculnya tanaman diatas permukaan tanah dimana tunas-tunas dari umbi yang telah dipotong setelah ditanam akan lekas tumbuh membentuk tanaman baru.

Umbi yang telah ditanam kemudian akan tumbuh membentuk tunas, daun dan akar secara bersamaan serta terus-menerus. Tahap ini diawali sejak terbentuknya daun pertama muncul, kegiatan fotosintesis kemudian dimulai sehingga peranan umbi induk sebagai pemasok karbohidrat dalam pertumbuhan tanaman sedikit demi sedikit berkurang terutama pada saat pembentukan anakan atau umbi baru. Pembentukan anakan merupakan suatu proses fisiologis yakni suatu bagian umbi di bawah permukaan tanah dirombak morfologisnya menjadi suatu organ yang mampu menyimpan karbohidrat dalam jumlah banyak. Hal ini sesuai dengan pendapat Wibowo (2005) bahwa pembentukan anakan baru diawali dari peranan umbi induk sebagai pemasok karbohidrat dirombak morfologisnya menjadi suatu bagian yang mampu menyimpan karbohidrat dalam jumlah banyak sehingga mendorong terbentuknya umbi samping dan anakan serta daun.

Faktor-faktor yang mempengaruhi pertumbuhan dan perkembangan tanaman antara lain faktor dari tanaman itu sendiri yang mencakup sifat genetik dari umbi yang digunakan dimana umbi yang digunakan bebas dari hama dan penyakit, memiliki kemampuan tumbuh yang tinggi. Zat pengatur tumbuh juga berperan dalam mendukung pertumbuhan tanaman sebagaimana yang diketahui dapat mempercepat pertunasan seperti auksin yang berperan dalam memacu pertumbuhan bagian meristem tanaman, sitokinin berperan dalam memacu pembelahan sel dan mendorong pembesaran sel. Hal ini sesuai dengan pendapat Rukmana ( 1994 ) bahwa zat pengatur tumbuh memegang peranan penting dalam mepercepat pertumbuhan tanaman seperti hormon auksin, sitokinin, giberelin.

\subsubsection{Bokashi Pupuk Kandang Ayam}

Hasil uji lanjutan menunjukkan bahwa perlakuan takaran bokashi pupuk kandang ayam $4 \mathrm{~kg}$ petak $^{-1}$ memberikan rata-rata tertinggi pada komponen pengamatan tinggi tanaman; jumlah daun; jumlah umbi; berat basah; berat kering dan umur panen. Hal ini disebabkan rendahnya unsur hara dalam tanah menyebabkan perlunya penambahan unsur hara melalui pemberian pupuk yang cukup dan seimbang. Hasil percobaan menunjukkan bahwa takaran bokashi pupuk kandang ayam 4 kg petak $^{-1}$ memberikan hasil lebih baik dibandingkan dengan takaran lainnya. Hal ini menunjukkan bahwa tingkat ketersediaan hara dalam tanah dengan penambahan bokashi pupuk kandang ayam $4 \mathrm{~kg}$ petak $^{-1}$ telah mencukupi areal pertanaman bawang merah yang akan menyediakan unsur hara yang seimbang untuk kebutuhan tanaman sejak memasuki fase vegetatif hingga fase generatif. Hal ini sejalan dengan yang dikemukakan oleh Suhardi ( 1990 ) bahwa untuk pertumbuhan yang normal, tanaman memerlukan unsur hara dan bila komponen tersebut dalam keadaan 
cukup dan seimbang sel-sel akan terus aktif dan giat melakukan pembelahan sehingga pertambahan tinggi tanaman, jumlah daun, diameter batang dan bobot segar tanaman dapat ditingkatkan.

Tinggi tanaman dan jumlah daun, jumlah umbi, berat basah, berat kering tanaman tertinggi diperoleh pada takaran $4 \mathrm{~kg}$ petak $^{-1}$. Hal ini disebabkan karena kandungan $\mathrm{N}$ pada pupuk yang diberikan dapat mendukung proses pembelahan sel dengan cepat yang menyebabkan adanya pengaruh terhadap pertambahan tinggi tanaman dan jumlah daun. Hal ini sesuai dengan pendapat Lingga (1999) bahwa nitrogen berperan dalam merangsang pertumbuhan tanaman khususnya batang, cabang, dan daun selain itu nitrogen juga penting dalam pembentukan hijau daun yang berguna dalam proses fotosintesis.

Bokashi pupuk kandang ayam mengandung bahan organik dalam jumlah besar dibandingkan pupuk kandang lainnya. Bokashi merupakan salah satu hasil permentasi bahan organik dengan inokulasi EM4 dapat digunakan sebagai pupuk organik untuk menyuburkan tanah dan meningkatkan produktivitas tanaman dengan biaya minimal dan mengurangi penggunaan pestisida. Hal ini sesuai dengan pendapat Wididana dan Muntoyah ( !999) bahwa bokashi mempunyai banyak keunggulan dibanding produk sejenis antara lain kandungan haranya sangat tinggi, kandungan mikroorganisme menguntungkan sangat tinggi, senyawa organik yang dikandungnya dapat cepat diserap oleh tanaman karena pembuatannya melalui proses fermentasi dengan waktu yang relatif cepat.

Pupuk kandang ayam mengandung bahan organik dalam jumlah yang besar. Bahan organik tersebut sangat bermanfaat dalam tanah khususnya karena segera melapuk dan meningkatkan kandungan humus dalam tanah. Bahan organik yang terdekomposisi melepaskan senyawa organik dan anorganik yang bervariasi sesuai jenis bahan organiknya. Senyawa karbohidrat dan protein mudah terdekomposisi menjadi ion-ion fosfat ( $\left.\mathrm{HPO}^{4-}\right)$, sulfat $\left(\mathrm{SO}_{4}^{2-}\right)$, nitrat $\left(\mathrm{NO}_{3}^{-}\right)$, amoniak $\left(\mathrm{NH}_{4}^{-}\right)$ dan air $\left(\mathrm{H}_{2} \mathrm{O}\right)$ serta beberapa unsur lainnya seperti kalsium. Hal ini sesuai dengan pendapat Sutanto ( 2004 ) bahwa unsur-unsur yang terdapat pada pupuk kandang ayam merupakan dasar utama pembuatan bokashi yang dilepas pada lingkungan perakaran dan selanjutnya dapat diserap oleh tanaman menyebabkan keberlangsungan aktivitas fisiologis tanaman seperti berlangsungnya fotosintesis guna pembentukan cadangan makanan untuk pertumbuhan dan perkembangan tanaman.

3.2.3. Interaksi Pemotongan Umbi dengan Bokashi Pupuk Kandang Ayam

Hasil analisis statistik menunjukkan bahwa tidak terdapat interaksi antara pemotongan umbi dan takaran bokashi pupuk kandang ayam pada parameter tinggi tanaman, jumlah daun, umur panen sedangkan pada parameter jumlah umbi, berat basah dan berat kering tanaman terdapat interaksi di antara keduanya. Terjadinya interaksi ini berarti terjadi hubungan yang saling menguntungkan dari dua taraf perlakuan. Pemotongan umbi yang diaplikasikan dengan pupuk bokashi sebagai pupuk organik menyebabkan pertambahan jumlah umbi, berat basah dan berat kering tanaman. Hal ini disebabkan karena bokashi merupakan kultur campuran dari beberapa mikroorganisme menguntungkan yang membutuhkan bahan organik sebagai nutrisinya, sedangkan bahan organik yang telah disediakan dalam bentuk bokashi yang berbahan dasar pupuk kandang ayam. Hal ini sesuai dengan pendapat Sutedjo et al (1991) bahwa mikroorganisme yang berperan dalam dekompopsisi pupuk kandang menyebabkan penghancuran atau pembakaran bahan organiknya berlangsung cepat.

Pupuk kandang sebagai bahan dasar pembuatan bokashi dapat menyebabkan peningkatan kadar $\mathrm{N}$ dalam tanah yang dapat dimanfaatkan oleh tanaman yang selanjutnya akan memperbaiki produksi tanaman. Unsur $N$ merupakan unsur esensial yang dibutuhkan oleh tanaman dalam jumlah yang besar. Unsur $\mathrm{N}$ yang cukup tinggi yangterkandung dalam pupuk kandang ayam menyebabkan pembelahan dan pembesaran sel-sel yang terjadi pada meristem apikal berlangsung cukup pesat. Unsur $\mathrm{N}$ berperan penting dalam merangsang pertumbuhan vegetatif tanaman. Hal ini sesuai dengan pendapat Setyamidjaja (1986) bahwa unsur nitrogen berperan penting 
dalam merangsang vegetatif tanaman yakni menambah tinggi tanaman dan merangsang pembentukan cabang.

Aktivitas fotosintesis guna pembentukan cadangan makanan untuk pertumbuhan dan perkembangan tanaman termasuk dalam mendukung potensi pertumbuhan generatif serta produksi serta berat brangkasan yang terbentuk. Jika kuantitas fotosintat yang dihasilkan lebih banyak berarti semakin banyak pula pasokan fotosintat yang akan digunakan untuk mendukung pembentukan biji sehingga biji yang dihasilkan mempunyai bobot dan jumlah yang semakin besar. Hal ini sesuai dengan pendapat Gardner, Pearce dan Mitchell (1991) bahwa semakin tinggi hasil fotosintesis semakin besar pula penimbunan cadangan makanan yang ditranslokasikan ke jaringan penyimpanan cadangan makanan dengan asumsi bahwa faktor lain seperti cahaya, air, suhu, dan hara dalam keadaan optimal.

Produksi yang diperoleh lebih rendah dibanding dengan produktivitas bawang merah varietas Bima yang bisa mencapai 10 ton per hektar. Hal ini mungkin disebabkan kondisi lahan pertanian mengalami krisis bahan organik sehingga dapat dikategorikan lahan marjinal. Sebagaimana yang dikemukakan oleh Hakim, dkk., ( 1986 ) bahwa lahan marjinal adalah lahan yang miskin hara, membutuhkan suplai hara yang lebih besar dibanding lahan lainnya. Oleh karena itu dibutuhkan upaya untuk memperbaiki produktivitas lahan pertanian yakni dengan pemberian bahan organik dalam bentuk bokashi pupuk kandang ayam yang dapat memperbaiki pertumbuhan dan produksi tanaman.

\section{PENUTUP}

\subsection{Kesimpulan}

1. Pemotongan umbi memberikan hasil terbaik pada tinggi tanaan pada umur 2 MST (21,36 cm), 4 MTS $(29,34 \mathrm{~cm}), 6$ MST $(34,14 \mathrm{~cm})$ dan 8 MST $(22,90 \mathrm{~cm})$. Jumlah daun umur 2 MST (14,10 helai), 4 MST (23,46 helai), 6 MST (27,51 helai), dan 8 MST (16, 57 helai); jumlah umbi $(11,33)$; berat basah $(776,67 \mathrm{~g})$; berat kering umbi $(443,33$ g).

2. Takaran bokashi pupuk kandang ayam $4 \mathrm{~kg}$ petak $^{-1}$ menghasilkan rata-rata tertinggi pada tinggi tanaman $(31,84 \mathrm{~cm})$, jumlah daun (26,53 helai) jumlah umbi $(11,33)$, berat basah $(776,67)$ dan berat kering umbi (443,33 g).

3. Terdapat interaksi yang berpengaruh nyata antara pemotongan umbi dan takaran bokashi pupuk kandang ayam 4 kg petak-1 yang berpengaruh terhadap pertumbuhan tanaman bawang merah

\subsection{Saran}

Sebaiknya dalam usaha peningkatan produksi tanaman bawang merah dilakukan pemotongan ujung umbi dan penambahan bahan organik ke dalam tanah dalam bentuk bokashi pupuk kandang ayam dengan takaran $4 \mathrm{~kg}$ petak $^{-1}$

\section{DAFTAR PUSTAKA}

Anjari Fadilla Nur Ramadhan, Titin Sumarni, 2018. Respon Tanaman Bawang Merah Terhadap Pupuk Kandang dan Pupuk Anorganik (NPK). Fakultas Pertanian Universitas Brawijaya. Jurnal Produksi Tanaman, Vol. 6. No. 5. 815-822.

Annisava AR dan Solfan B. 2014. Agronomi Tanaman Hortikultura. Aswaja Pressindo: Yogyakarta (ID).

Balai Penelitian Tanah. 2009. Teknik irigasi diminati petani bawang donggala. Warta Penelitian dan Pengembangan Pertanian Vol. 31 N.o 62009.

Gardner. F.P, R.B. Pearce dan R.L Mitchell. 1991. Pysiologi of Crop Plants ( Fisiologi Tanaman Budidaya : Terjemahan Herawati Susilo ). Penerbit Universitas Indonesia. Jakarta. 
Handayani SA. 2014. Optimalisasi Pengelolaan Lahan untuk Sayuran Unggulan Nasional. Julianto, editor. Tabloid Sinar Tani Senin 28 April 2014 [Internet].[Waktu dan tempat pertemuan tidak diketahui]. Jakarta (ID): Sinartani.. Tersedia pada: http://tabloidsinartani.com/content/read/optimalisasi-pengelolaan-lahan-untuksayuranunggulan-nasional/.

Lingga , P. 1999. Petunjuk Penggunaan Pupuk. Penebar Swadaya. Jakarta.

Lingga, P., dan Marsono. 2000. Petunjuk penggunaan pupuk. Penebar Swadaya. Jakarta.

Mursiani, A. S. 2000. Kajian Penggunaan Berbagai Varietas Bawang Merah di Kodya Malang. Lembaga Penelitian Muhammadiyah.

Pitojo, S., 2003. Benih Bawang Merah. Kanisius, Yogyakarta.

Suwandi , 2014 Budi Daya Bawang Merah di Luar Musim Teknologi Unggulan Mengantisipasi Dampak Perubahan Iklim Badan Penelitian dan Pengembangan Pertanian Kementerian Pertanian.

Sutanto, R. 2004. Penerapan Pertanian Organik. Pemasyarakatan dan Pengembangannya, Kanisius. Yogyakarta.

Sutedjo, M,M. Kartasapoetra dan Sastroatmojo. 1991. Mikrobiologi Tanah. Rineka Cipta. Jakarta.

Wibowo, S. 2005. Budidaya Bawang Merah dan Pasca Panen. Penebar Swadaya, Jakarta.

Wididana, G.N. dan Muntoyah, 1999. Teknologi EM-4, Dimensi Baru dalam bidang Pertanian Mederen. Institut Pengembangan Sumber Daya Alam (IPSA), Jakarta. 